\title{
The Adult Netherlands Twin Register: Twenty-Five Years of Survey and Biological Data Collection
}

\author{
Gonneke Willemsen, ${ }^{1,2}$ Jacqueline M. Vink, ${ }^{1,3}$ Abdel Abdellaoui, ${ }^{1,3}$ Anouk den Braber, ${ }^{1,3}$ \\ Jenny H. D. A. van Beek, ${ }^{1,2}$ Harmen H. M. Draisma, 1,2 Jenny van Dongen, 1,2 Dennis van 't Ent, 1,3 \\ Lot M. Geels, ${ }^{1,2}$ Rene van Lien, ${ }^{1,2}$ Lannie Ligthart, ${ }^{1,2}$ Mathijs Kattenberg, ${ }^{1}$ Hamdi Mbarek, ${ }^{1,2}$ \\ Marleen H. M. de Moor, ${ }^{1,2}$ Melanie Neijts, ${ }^{1,2}$ Rene Pool, ${ }^{1,2}$ Natascha Stroo, ${ }^{1}$ Cornelis Kluft, ${ }^{4}$ \\ H. Eka D. Suchiman, ${ }^{1,5}$ P. Eline Slagboom, ${ }^{5}$ Eco J. C. de Geus, ${ }^{1,2,3}$ and Dorret I. Boomsma ${ }^{1,2,3}$ \\ ${ }^{1}$ Department of Biological Psychology, VU University Amsterdam, Amsterdam, The Netherlands \\ ${ }^{2}$ EMGO+ Institute for Health and Care Research, Amsterdam, The Netherlands \\ ${ }^{3}$ Neuroscience Campus Amsterdam, Amsterdam, The Netherlands \\ ${ }^{4}$ Good Biomarker Sciences, Leiden, The Netherlands \\ ${ }^{5}$ Molecular Epidemiology, Leiden University Medical Center, Leiden, The Netherlands
}

Over the past 25 years, the Adult Netherlands Twin Register (ANTR) has collected a wealth of information on physical and mental health, lifestyle, and personality in adolescents and adults. This article provides an overview of the sources of information available, the main research findings, and an outlook for the future. Between 1991 and 2012, longitudinal surveys were completed by twins, their parents, siblings, spouses, and offspring. Data are available for 33,957 participants, with most individuals having completed two or more surveys. Smaller projects provided in-depth phenotyping, including measurements of the autonomic nervous system, neurocognitive function, and brain imaging. For $46 \%$ of the ANTR participants, DNA samples are available and whole genome scans have been obtained in more than 11,000 individuals. These data have resulted in numerous studies on heritability, gene $x$ environment interactions, and causality, as well as gene finding studies. In the future, these studies will continue with collection of additional phenotypes, such as metabolomic and telomere length data, and detailed genetic information provided by DNA and RNA sequencing. Record linkage to national registers will allow the study of morbidity and mortality, thus providing insight into the development of health, lifestyle, and behavior across the lifespan.

- Keywords: twin family studies, gene finding, longitudinal surveys, biobank, DNA

Since its establishment in 1987, the Netherlands Twin Register (NTR) has undertaken two lines of longitudinal research. The first one concentrates on young twins who are followed from birth onwards with a focus on the development of emotional and behavioral problems [the Young NTR (YNTR), described in detail by Van Beijsterveldt et al., 2013], while the second research line focuses on adolescent and adult twins and their family members. These participants are followed in time to study the role of genes and environment and their interaction in individual variation in personality, lifestyle, and health, and the development of disease and psychopathology. For this adult group of participants, the Adult NTR (ANTR), the current article provides an overview of the data resources brought together over the past 25 years. Sample composition, data collection by surveys, dedicated studies based on visits to laboratories and hospitals, biological sample collections, and main genotyp- ing projects are summarized. We present some of the main findings and our vision on the future of ANTR studies.

\section{Participants}

Adolescent and young adult twins were recruited over a 3year period in 1991-1993 through city council offices in the Netherlands (for a detailed description, see Boomsma et al., 2002, 2006; Koopmans et al., 1999). Recruitment of additional participants continued through other approaches,

RECEIVED 20 September 2012; ACCEPTED 6 November 2012.

ADDRESS FOR CORRESPONDENCE: Gonneke Willemsen, Department of Biological Psychology, VU University Amsterdam, van der Boechorststraat 1, 1081 BT Amsterdam, the Netherlands. E-mail: a.h.m.willemsen@vu.nl 
TABLE 1

Overview of the Number of ANTR Participants in the Period 1991-2012, Stratified by Relation and Sex, and Including Year of Birth Information

\begin{tabular}{lllll}
\hline & & $N$ & $\begin{array}{l}\text { Year of birth } \\
\text { mean (SD) }\end{array}$ & $\begin{array}{l}\text { Year of birth } \\
\text { range }\end{array}$ \\
\hline Multiples & Male & 6,116 & $1976(12)$ & $1918-1996$ \\
& Female & 9,679 & $1975(13)$ & $1909-1996$ \\
Siblings & Brother & 1,926 & $1971(14)$ & $1914-1995$ \\
& Sister & 2,479 & $1970(14)$ & $1911-1998$ \\
Parents & Father & 4,939 & $1949(9)$ & $1912-1989$ \\
& Mother & 6,325 & $1952(10)$ & $1906-1983$ \\
Spouses & Male & 1,324 & $1966(11)$ & $1924-1985$ \\
Offspring & Female & 739 & $1970(11)$ & $1928-1989$ \\
& Son & 144 & $1977(8)$ & $1950-1995$ \\
& Daughter & 286 & $1978(8)$ & $1944-1995$ \\
\hline
\end{tabular}

Note: Individuals who have multiple roles in the ANTR (e.g., a spouse of a twin who is also a sibling of a twin) are only presented once in these figures. Preference was given to the role that was biologically closest to the twin (e.g., as sibling of twin, not as spouse of twin). Individuals who are registered in both the ANTR and YNTR are present in their role in the ANTR (e.g., a mother of YNTR twins who is an ANTR twin herself adds to the number of female twins in the table).

including advertising in NTR newsletters and the Internet. New participants can still register, though there are no current major recruitment efforts, as there is substantial increase in participants from the YNTR: when the young twins reach adulthood they are invited to take part in ANTR research, together with their siblings and parents (see Van Beijsterveldt et al., 2013).

At the start of the ANTR, twins and their parents were included in research projects, but over the past 25 years siblings, spouses, and offspring of twins also have been invited. A total of 33,957 individuals from the Netherlands have participated in ANTR research. More than $80 \%$ of these subjects are still registered as active participants and receive invitations for ongoing and future studies. The main reasons for discontinuation of the NTR registration are unwillingness to continue participation in research $(74 \%)$, moving to a different address without notification (12\%), and death $(8 \%)$. The ANTR sample contains 8,159 participants who originally enrolled in the YNTR and 1,632 participants who are registered in both the ANTR and YNTR, but with different roles (e.g., a parent of young twins who is also the sibling of an adult twin or parents of young twins who themselves are twins). An additional 4,491 individuals are registered in the ANTR as willing to participate, but have not yet actively participated in ANTR research and are therefore not included in the overviews in this article. Table 1 provides a breakdown of the sample that participated in ANTR research by sex and role in the family (when they have multiple roles; e.g., as parent and twin, one role was selected), and information on year of birth. As shown, the sample includes twins but also parents, siblings, and spouses of twins and siblings, as well as offspring of twins and siblings.

\section{Survey Data Collection}

Since 1991 the ANTR sends out a 2- to 3-yearly survey on health, lifestyle, and personality to its participants. Table 2 provides an overview of the number of ANTR participants for each survey till August 2012.

The first survey was sent out in 1991 to 2,375 families who had responded to a first invitation for participation in the NTR that was sent to 4,036 addresses. Each family received questionnaire booklets for the father, mother, and twin pair (though it was not known at the time whether a singleparent household was approached). Completed questionnaires were received from 1,703 families of the 2,375 families (72\%). In 1993 a second survey was sent out to the families that participated in the first survey and to 1,987 additional new families for whom addresses were obtained in 1992 and 1993. A total of 3,690 families were approached with questionnaire booklets for the twin pair, father, and mother and surveys were returned by 2,171 families (59\%). For the third survey, the families that participated in one of the first two waves were approached with booklets for the twins and the parents, as well as booklets for two additional siblings. Of the 2,712 families approached, 1,743 families (64\%) returned one or more booklets.

The fourth survey was sent to twins and siblings who had participated in the past and an effort was made to also include extra siblings (who were registered after the 1995

\section{TABLE 2}

Participation in the ANTR Surveys in the Time Period 1991-2012

\begin{tabular}{|c|c|c|c|c|c|c|c|c|c|}
\hline & Survey 1 & Survey 2 & Survey 3 & Survey 4 & Survey 5 & Survey 6 & Survey $7^{*}$ & Survey $8^{\S}$ & Survey $9^{\S}$ \\
\hline Year & 1991 & 1993 & 1995 & 1997 & 2000 & 2002 & 2004-2008 & 2009-2012 & 2011-2012 \\
\hline Multiples & 3,391 & 4,234 & 3,425 & 3,232 & 4,613 & 4,530 & $5,211(+512)$ & $5,334(+3,080)$ & $3,684(+1,886)$ \\
\hline Siblings & 3 & 7 & 1,482 & 1,510 & 1,472 & 1,455 & $1,585(+56)$ & $1,400(+471)$ & $891(+333)$ \\
\hline Parents & 3,037 & 3,671 & 3,240 & 5 & 26 & 2,840 & $3,287(+37)$ & $2,979(+2,485)$ & $2,162(+1,878)$ \\
\hline Spouses & - & - & 1 & - & 682 & 1,462 & 961 & 824 & 619 \\
\hline Offspring & - & - & - & - & - & - & 329 & 288 & 186 \\
\hline Total & 6,431 & 7,912 & 8,148 & 4,747 & 6,793 & 10,287 & $11,373(+605)$ & $10,825(+6,036)$ & $7,542(+4,097)$ \\
\hline Response rate & $72 \%$ & $59 \%$ & $64 \%$ & $52 \%$ & $52 \% \ddagger$ & $44 \% \ddagger$ & $43 \%^{\ddagger}$ & $41 \% \ddagger$ & $42 \%$ \\
\hline
\end{tabular}

Note: The number in brackets indicates the additional number of YNTR participants that transferred to ANTR research.

* In addition, Survey 7 was also completed by 1,800 participants in the Flemish Twin Register.

\$The data collection for this survey is ongoing.

Estimated response rates, allowing for the fact that some addresses for participants may have been incorrect (see text). 


\section{TABLE 3}

Longitudinal Participation in ANTR Surveys in the Time Period 1991-2012

\begin{tabular}{|c|c|c|c|c|c|c|c|c|c|c|c|c|}
\hline & \multicolumn{9}{|c|}{ ANTR } & \multicolumn{3}{|c|}{ YNTR* } \\
\hline & $1 x$ & $2 x$ & $3 x$ & $4 x$ & $5 x$ & $6 x$ & $7 x$ & $8 x$ & $9 x$ & $1 x$ & $2 x$ & $>3$ \\
\hline Multiple & 2,599 & 2,244 & 1,920 & 1,278 & 1,088 & 750 & 606 & 420 & 238 & 1,923 & 1,451 & 221 \\
\hline Sibling & 1,002 & 773 & 513 & 375 & 322 & 266 & 142 & 1 & 1 & 346 & 229 & 19 \\
\hline Parent & 2,137 & 1,716 & 1,279 & 685 & 507 & 594 & 423 & 1 & & 1,406 & 1,484 & 17 \\
\hline Spouse & 762 & 542 & 341 & 318 & 82 & & & & & & & \\
\hline Child & 165 & 136 & 122 & & & & & & & & & \\
\hline
\end{tabular}

Note: *This is an overview of ANTR participation, for YNTR participants additional information is available (see Van Beijsterveldt et al., 2013).

survey). The survey collection used an individual approach; booklets were sent to 7,989 individuals, rather than to families, and 4,747 booklets (59\%) were returned. In 2000, the invitation strategy was expanded with questionnaires for the fifth survey sent out to all twins and siblings $(N=14,288)$ for whom addresses were available at that time, irrespective of previous participation. In addition, twins between 25 and 30 years of age received a booklet for their spouse, with the request to give this invitation to their partner if they had one. Booklets were received for 6,085 twins and siblings (43\%) and for 682 spouses and 26 parents. It is likely though that a number of addresses were incorrect, especially for individuals who never participated. Looking at individuals who participated previously and therefore were more likely to be reachable at the address in the database, 4,032 of the 8,329 of the twins and siblings (48\%) participated. This, however, does not take into account that individuals will have moved in the time period between surveys without providing the NTR with their new address. Assuming that $15 \%$ of the addresses was incorrect (a low estimate compared to the estimates in later non-response studies), the actual response rate is estimated at $52 \%$.

For Survey 6, all persons registered with the ANTR (multiples, siblings, parents, and spouses) were invited to take part. Of the 29,217 surveys sent out, 10,287 (35\%) were returned. To determine the nature of this lower response rate, several non-response studies were carried out that indicated that $38-42 \%$ of the addresses in our database were incorrect at that time and a conservative correction, allowing for $30 \%$ incorrect addresses, would lead to an estimate of $44 \%$ response rate for Survey 6 . From Survey 7 onwards, all individuals registered with the ANTR (multiples, siblings, parents, and spouses) were invited to take part and adult children of twins and siblings also received an invitation. In November 2004, the 7 th survey was sent to 28,859 individuals, of which 8,617 returned the survey, providing a response rate of $30 \%$. Again, non-response studies were conducted. Based on these studies, it was estimated that at the time $36 \%$ of the invitations did not reach the intended participants. A subset of twins and family members $(N=605)$ from the YNTR completed an abbreviated version of Survey 7, as part of several laboratory projects.
Due to continued effort to retrieve addresses and reach out to participants, and by sending the survey to participants upon registration, the total number of completed Survey 7 booklets was 11,978 by the end of 2008 (allowing for $20 \%$ incorrect address under the non-respondents leads to a response rate estimate of $43 \%$ ). Survey 7 was also sent out to participants in the Flemish Twin Register, for which 1,800 surveys were returned.

As also described in the article by Van Beijsterveldt et al. (2013), twins from the YNTR who have reached the age of 18 years are enrolled in the ANTR. The first survey for which this occurred was Survey 8 . Survey 8 was also the first survey that could be completed online. Participants first received an invitation letter at home with a login for the online survey. As stated in the letter, they were automatically sent a printed questionnaire booklet when the Internet survey was not completed within 6 weeks. In total, 47,122 individuals were invited for participation in Survey 8 . The number of surveys completed was 16,861 , resulting in a response rate of $36 \%$. As a result of earlier non-response studies, we did not sent out surveys to families where none of the family members had ever participated and who were registered at the start of the NTR. However, considering the age of our participants and the time between this survey and the previous one, a number of surveys will still have gone to an incorrect address. According to several small non-response studies this would be the case for $15-30 \%$ of the non-respondents. Based on a general percentage of $20 \%$ incorrect addresses, the actual response rate is $41 \%$. For Survey 9, the online option was offered as the first choice, but a hard copy of the survey could be obtained by request. Data collection for this survey is still ongoing but this short survey has already been completed by 11,639 participants, $42 \%$ of the 27,892 sent.

The longitudinal character of the survey collection is represented in Table 3. As described above, the approaches for the surveys varied while recruitment for the NTR continued, so not everyone had the opportunity to participate in all surveys. The maximum number of possible participations was 9 for twins, 6 for parents, 7 for siblings, and 5 for spouses. As indicated, the number of sibling and spouses invited in the surveys was limited due to the selection 
TABLE 4

Broad Overview of the Survey Data Collection in the ANTR 1991-2012

\begin{tabular}{|c|c|c|c|c|c|c|c|c|c|}
\hline & 1991 & 1993 & 1995 & 1997 & 2000 & 2002 & 2004 & 2009 & 2011 \\
\hline $\begin{array}{l}\text { Demographics (date of birth, marital status, } \\
\text { family size, religion, zygosity) }\end{array}$ & $x$ & $x$ & $x$ & $x$ & $x$ & $x$ & $x$ & $x$ & $x$ \\
\hline $\begin{array}{l}\text { Lifestyle (alcohol use, smoking, other drug } \\
\text { use, sport participation) }\end{array}$ & $\mathrm{x}$ & $\mathrm{x}$ & $\mathrm{x}$ & $\mathrm{x}$ & $\mathrm{x}$ & $\mathrm{x}$ & $\mathrm{x}$ & $\mathrm{x}$ & $\mathrm{x}$ \\
\hline $\begin{array}{l}\text { Socio-economic status (education and } \\
\text { profession) }\end{array}$ & $x$ & $x$ & $x$ & $x$ & $x$ & $x$ & $x$ & $x$ & - \\
\hline Personality traits & $A B V$ & $A B V$ & - & ABV & $A B V$ & - & NEO-FFI & NEO-FFI & - \\
\hline Externalizing/internalizing & YSR & - & YSR & YSR & YSR & AnxDep & - & ASR & AnxDep \\
\hline Sensation seeking & $\mathrm{x}$ & $\mathrm{x}$ & - & $\mathrm{x}$ & $\mathrm{x}$ & $\mathrm{x}$ & - & $\mathrm{x}$ & - \\
\hline ADHD & - & - & - & - & - & - & CAARS & CAARS Index & - \\
\hline OCD symptoms & - & - & - & - & - & PADUA & - & PADUA & - \\
\hline Depression & - & BDI & - & $\mathrm{BDI}$ & - & - & - & HADS & - \\
\hline Borderline personality disorder & - & - & - & - & - & - & PAI-BOR & PAI-BOR & - \\
\hline $\begin{array}{l}\text { Health (subjective health, chronic disease, } \\
\text { medication) }\end{array}$ & $x$ & $x$ & $x$ & $x$ & $x$ & $x$ & $\mathrm{x}$ & $\mathrm{X}$ & $x$ \\
\hline Body composition (height, weight) & $\mathrm{x}$ & $\mathrm{x}$ & $\mathrm{x}$ & $\mathrm{x}$ & $x$ & $\mathrm{x}$ & $\mathrm{x}$ & $\mathrm{x}$ & $\mathrm{x}$ \\
\hline Well being and life satisfaction & - & - & - & - & - & $\mathrm{x}$ & - & $\mathrm{X}$ & - \\
\hline Life events & - & - & - & - & $x$ & $\mathrm{x}$ & $x$ & $x$ & - \\
\hline
\end{tabular}

Note: $X$ = included in survey; ABV = Amsterdamse Biografische Vragenlijst (similar to the Eysenck Personality Questionnaire); NEO-FFI = NEO Five-Factor Inventory; YSR = Youth Self-Report; AnxDep = Anxiety Depression subscale; ASR = Adult Self-Report; CAARS = Connors Adult ADHD Rating Scales; CAARS Index = Subscale of CAARS; PADUA = Padua Inventory for Obsessive-Compulsive Disorder; BDI = Beck Depression Inventory; HADS = Hospital Anxiety and Depression Scale; PAI-BOR = Personality Assessment Inventory-Borderline Features.

This table presents an overview of the most prominent variables in the surveys. Additional information in one or two surveys is available; for example, type-A and cognitive failures in 1991, Spielberger trait anger in 1991 and 1993, hoarding and tics in 2009.

procedures used (e.g., for Survey 5, only twins within a specific age range received an invitation for their spouse to participate).

Table 4 provides an overview of the information obtained in each of the surveys. Although there is overlap between the surveys in the questions and scales included, the main topics of the surveys differ somewhat depending on the central research question. For instance, Survey 6 (2002) asked in detail for information on sport participation and wellbeing, Survey 7 (2004-2008) focused on personality, borderline personality disorder, and attention deficit hyperactivity disorder (ADHD), Survey 8 on alcohol use, smoking, and personality, while in Survey 9, dental fear, migraine, and pain were the focus of the study. Recently, we started asking participants to complete a short questionnaire upon registration to provide some baseline data on demographics, family situation, and lifestyle. At the moment, this baseline survey has been completed by 523 ANTR participants.

The first NTR studies in adolescent and adult twins focused on cardiovascular phenotypes (Boomsma et al., 1996; Snieder et al., 1997) and on brain function (Van Beijsterveldt et al., 2001) as assessed by electroencephalograpy (EEG) and event-related potentials (ERP). Such indepth phenotyping studies often included the collection of biological samples, and have continued alongside the large survey projects. Table 5 provides an overview of these other projects within the ANTR, with the number of participants included and the setting in which they took place. Some individuals took part in multiple projects: for instance, 110 individuals participated in one of the cardiovascular projects, underwent neurocognitive testing, and had an MRI scan.

\section{DNA Collection}

Within the ANTR, there have been several large DNA collection efforts: blood samples were collected in the three cardiovascular projects indicated in Table 5 and prominently as part of the first NTR-biobank project $(N=9,530$, Willemsen et al., 2010) and a recent second NTR-biobank project $(n=517)$. Buccal swabs have been collected as part of two large studies on anxious depression $(N=2,682$; Boomsma et al., 2000) and nicotine addiction $(N=1,014)$ and in multiple smaller lab studies. In most of these studies, DNA samples have been used for zygosity assessment. In total, we currently have DNA samples for 15,437 (45\%) of the participants in ANTR research. For various subsets of individuals multiple samples are present, either as bloodblood, buccal-buccal, or blood-buccal combinations. This availability of longitudinal samples provides unique opportunities such as the study of epigenetic changes over time (Talens et al., 2012) or the assessment of copy number variants (CNVs; Ehli et al., 2012; Scheet et al., 2012).

\section{Zygosity Assessments}

Most twins as well as their parents provided answers to survey questions on the similarity of the twins in eye color, hair color, face color, and facial characteristics (the same/somewhat the same/not the same). They also indicated whether the twins were sometimes mistaken for each other as a child by their parents, other family members, and strangers (yes/no). Based on the answers to these questions, twin zygosity was determined for every occasion and person separately. In short, twins who were equal on most of the physical characteristics and were confused by two or 
TABLE 5

Overview of Specific Projects Within the ANTR 1987-2012

\begin{tabular}{|c|c|c|c|c|c|}
\hline Study & Selection & $N$ & Reference & Selection of variables & Specifics \\
\hline Cardiovascular & $\begin{array}{l}\text { Adolescent twins and } \\
\text { parents }\end{array}$ & 642 & Boomsma et al., 1996 & HR, HRV, PEP, BP, lipids & Lab: rest and stress measures \\
\hline Cardiovascular & Adult twins & 427 & Snieder et al., 1997 & HR, HRV, PEP, BP, lipids & Lab: rest and stress measures \\
\hline Cardiovascular & Adult twins and sibs & 1,408 & Kupper et al., 2005, 2006 & HR, HRV, PEP, cortisol & 24-hour ambulatory assessment \\
\hline Depression & $\begin{array}{l}\text { Adults twins, sibs, } \\
\text { spouses }\end{array}$ & 1,438 & Boomsma et al., 2002, 2008 & Lifetime depression & CIDI telephonic interview \\
\hline EEG/cognition & Adolescent twins & 426 & Van Beijsterveldt et al., 2001 & $\begin{array}{l}\text { EEG indices, cognitive task } \\
\text { performance }\end{array}$ & Lab visit \\
\hline EEG/cognition & Adult twins and sibs & 785 & Posthuma et al., 2002, 2005 & $\begin{array}{c}\text { EEG indices, cognitive task } \\
\text { performance, } \mathrm{HR}, \mathrm{BP}\end{array}$ & Lab visit \\
\hline MRI & Adult twins and sibs & 458 & $\begin{array}{l}\text { Baaré et al., 2001; den Braber } \\
\text { et al., 2011; De Geus et al., } \\
\text { 2007b }\end{array}$ & Structural MRI & Hospital visit \\
\hline MRI & Adult twins and sibs & 314 & $\begin{array}{l}\text { Den Braber et al., 2012; } \\
\text { Wolfensberger et al., } 2008\end{array}$ & Functional MRI & Hospital visit \\
\hline Diabetes & Adult twins and sibs & 189 & Simonis-Bik et al., 2008 & $\begin{array}{l}\text { Beta cell function, glucose } \\
\text { tolerance }\end{array}$ & $\begin{array}{l}\text { Hospital and home visit, } \\
\text { including euglycemic clamp, } \\
\text { OGT test }\end{array}$ \\
\hline Asthma & $\begin{array}{l}\text { Adolescent twins and } \\
\text { parents }\end{array}$ & 425 & Wu et al., 2010 & $\begin{array}{l}\text { Lung function, skin prick to } \\
\text { allergens, bronchial } \\
\text { hyper-responsiveness, } \\
\text { lgE }\end{array}$ & Hospital visits \\
\hline DZ twinning & Twin mothers (sisters) & 1,594 & $\begin{array}{l}\text { Hoekstra et al., 2008; Painter } \\
\text { et al., } 2010\end{array}$ & $\begin{array}{l}\text { Birth data on twin and sibs, } \\
\text { fertility }\end{array}$ & Interview, NTR biobank \\
\hline
\end{tabular}

Note: $\mathrm{HR}=$ heart rate; HRV = heart are variability; PEP = pre-ejection period; $\mathrm{BP}=$ blood pressure; EEG = electroencephalography; MRI = Magnetic resonance imaging; IgE $=$ Immunoglobilin $E ;$ OGT test $=$ oral glucose tolerance test.

more of the groups were judged to be monozygotic (MZ). Twins who differed on two or more of the physical characteristics and/or were not mistaken for each other by two or more of the groups were seen as dizygotic (DZ). Next, all individual ratings of the parents and twins were combined to determine one measure of twin zygosity per twin pair. ANTR questionnaire data on zygosity were available for 4,361 same-sex pairs. Judgment was consistent across multiple occasions and/or raters for 2,958 (67.8\%) and inconsistent for $615(14.1 \%)$ of the pairs. For the remaining $788(18.1 \%)$ pairs only one rating was present. When there was inconsistency over time and persons, the majority of ratings determined the final outcome. In case of equal numbers of $\mathrm{MZ}$ and $\mathrm{DZ}$ ratings, the outcome was set to $\mathrm{DZ}$.

For 1,730 same-sex twin pairs (average birth year $=1969$, $S D=11$ ), zygosity was available from both DNA polymorphisms and ANTR questionnaires. If multiple reports were available and no inconsistencies existed for the questionnaire reports ( $N=1,346$ pairs), the correspondence with DNA zygosity was $98.4 \%$. When also including zygosity outcomes based on single judgments (total $N=1,421$ pairs), the correspondence was $97.6 \%$ and when including inconsistent questionnaire reports (total $N=1,730$ pairs), the correspondence with DNA zygosity was $96.1 \%$. For YNTR twins that enrolled in ANTR research, zygosity assessment was also available from earlier studies (see Van Beijsterveldt et al., 2013) and combining all available survey and DNA information provided us with a zygosity measure for $96 \%$ of the twins pairs of 18 years and older. The sample of ANTR participants includes 6,898 complete twin pairs (3,176 MZ, 2,068 same-sex DZ, 1,564 opposite-sex DZ, and 90 missing zygosity). In addition, there are 353 individuals who are part of a triplet and 1,739 twin individuals who participated in ANTR research without their co-twin (463 MZ, 409 samesex DZ, 598 opposite-sex DZ, 269 missing zygosity). This last group consisted mainly of young twins who enrolled in the ANTR.

\section{DNA Marker Data}

The first sets of genome-wide DNA marker data consisted of micro-satellite markers, measured in DNA extracted from either whole blood or buccal swabs and genotyped mainly by the Mammalian Genotyping Service in Marshfield and the Molecular Epidemiology Section of the Leiden University Medical Centre (Hottenga et al., 2007; Saviouk et al., 2011). If genotyping is considered to be successful when 250 or more autosomal markers are genotyped, the resulting data set contains data for 2,694 ANTR participants.

The next sets of genome-wide data came from short nucleotide polymorphism (SNP) microarrays. Data were obtained as part of several projects that were designed for genome-wide association (GWA) projects. For 1,982 participants in the first biobank project, Affymetrix Perlegen 5.0 genotyping was obtained as part of a Genetic Association Information Network project on depression (Boomsma et al., 2008; Sullivan et al., 2009). These SNP data have been included in several large gene-finding consortia. As part of an international twin register collaboration, Illumina 370 genotyping became available for $166 \mathrm{MZ}$ female twins (one twin genotyped per pair). Next, 24 depression cases were 


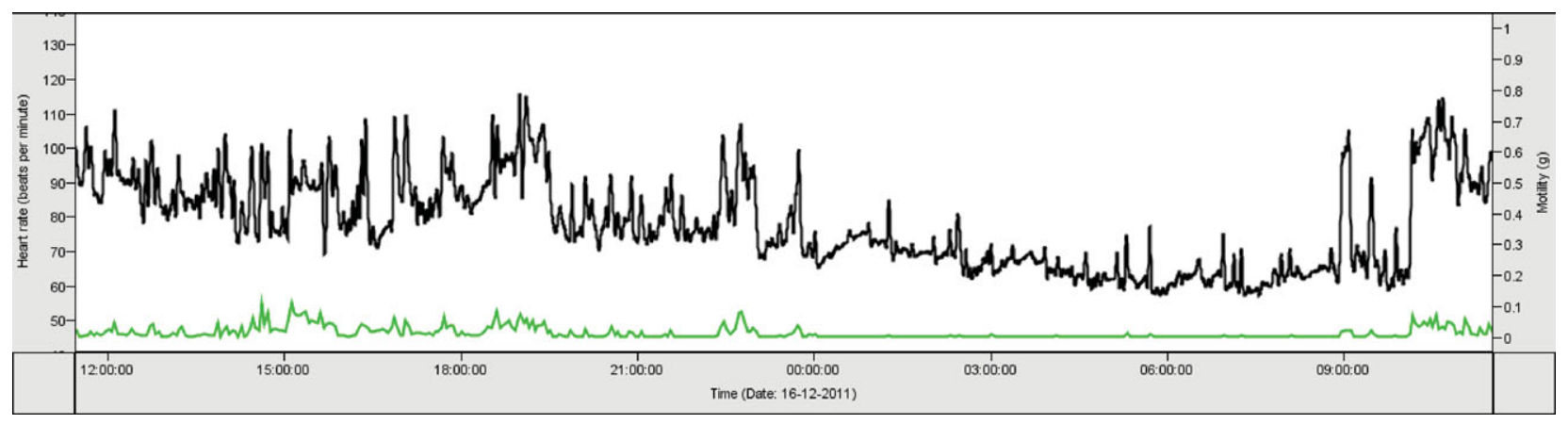

FIGURE 1

(Colour online) Figures included in reports to participants who underwent 24-hour ambulatory monitoring of cardiovascular function and motility.

Note: The upper line (black, left axis) indicates the number of beats per minute. The lower line (green, right axis) indicates the degree of motility.

genotyped on Affymetrix 5.0. The next large genotyping project provided Illumina 660 data on 1,340 participants, and this data set has often been used as a separate replication sample (referred to as NTR2). Also, Illumina Omni Express $1 \mathrm{M}$ genotyping data were obtained for 439 persons (parents and one of their children). Recently, two large projects were funded by the National Institute of Mental Health (NIMH) as a result of the American Recovery and Reinvestment Act in YNTR and ANTR twins. Genome-wide SNP and CNV genotyping was performed on Affymetrix $6.0(N=5,056$ ANTR participants). After quality control and selecting a single sample (the best one according to quality control) for individuals with multiple samples, the data of the platforms have now been merged into a single data set $(N=9,910)$. This merged set has been imputed together with the SNP data from the Netherlands Study of Anxiety and Depression against several reference sets, including HapMap panels $\mathrm{H} 2$ and the 1000 Genomes panel.

Principal components have been determined to identify ethnic outliers (Abdellaoui et al., submitted) and in general the results from the principal component analysis confirmed the information regarding place of birth as indicated in the surveys. For example, in the Dutch population in 2002 more than 700,000 individuals were first- or secondgeneration immigrants from Indonesia or Suriname (Alders, 2002). We have an additional 1,285 samples on Affymetrix 6.0 that have not yet been added to the main data set and another 1,000 samples are currently being genotyped at the Avera Institute for Human Genetics (South Dakota, USA).

Candidate genes have been measured in several subsets totaling more than 2,000 individuals. These measured genes include candidate genes related to depression (e.g., SERT), ADHD (e.g., DRD5, SNAP25), and physical functioning (e.g., FTO, ApoE). In addition, repeat polymorphisms (VNTRs) have been determined in a subset of samples, and as part of a study on diabetes, the amount of mitochondrial
DNA was determined for 329 participants (Reiling et al., 2010).

In the two NTR-biobank projects, materials were also obtained for the creation of immortalized cell lines and for RNA extraction (Willemsen et al., 2010). More than 8,500 lymphocyte-based cell lines have now been successfully established (success rate of $>99 \%$ ) and cDNA has been created for RNA samples from whole blood. These materials are stored at the NIMH repository of the Rutgers University Cell and DNA Repository (RUCDR) in New Jersey. As part of an NIMH project on depression, RNA expression levels of 49,293 transcripts were obtained for 3,495 ANTR participants using the U219 array (Jansen et al., submitted).

\section{Feedback to Participants}

Persons registered with the NTR receive a yearly newsletter, Twinfo, that provides a general update on recent research findings (www.tweelingenregister.org/twinfo [in Dutch]). Participants in specific research projects generally receive more personalized feedback. For instance, participants in the NTR Biobank received information about their cholesterol levels, while participants in ambulatory monitoring received an overview of their heart rate throughout their daily activities (see Figure 1) and participants in a neuropsychological test battery received an overview of their scores as a graph (see Figure 2), with an explanation of their scores.

In response to the frequent requests by participants for more detailed feedback, the NTR is presently building an NTR portal. This will allow individual feedback to the large number of participants in survey studies, in the form of, for instance, an individually tailored health profile or a personality profile.

\section{Research Projects}

With the help of more than 33,900 adolescent and adult men and women, the ANTR has contributed significantly 


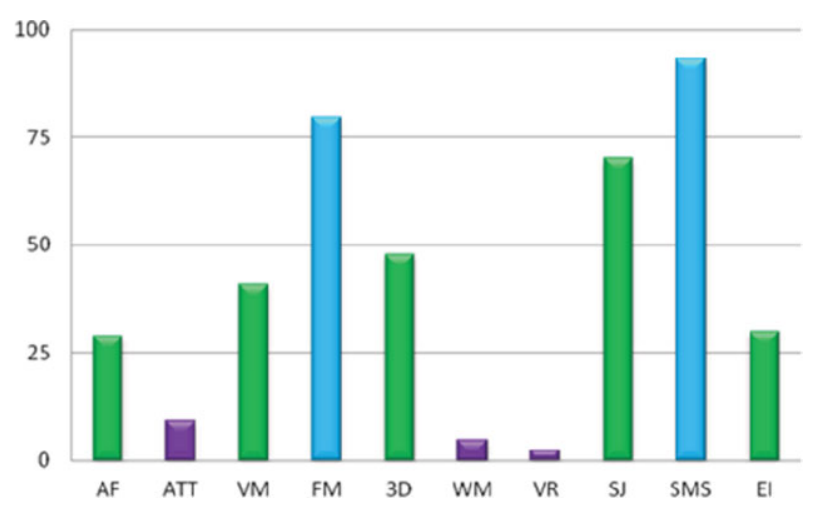

FIGURE 2

(Colour online) Figures included in reports to participants who underwent a series of neuropsychological tests.

Note: The bars indicate the score for the neuropsychological tests, presented as percentages (high percentages indicated a performance better than average, low percentages a performance less than average). $A F=$ abstraction and flexibility; $A T T=$ attention; $\mathrm{VM}=$ verbal memory; $F M=$ face memory; $3 D=3 D$ spatial memory; $\mathrm{WM}=$ working memory; $\mathrm{VR}=$ verbal reasoning; $\mathrm{SJ}$ = spatial judgment; SMS = sensorymotor speed; $\mathrm{El}=$ emotion identification.

to the understanding of the causes of individual variation in health, behavior, and personality. Although the NTR was originally founded to conduct twin studies, the large number of publications generated by the NTR also includes epidemiological studies exploring the change in prevalence of behaviors, such as sport participation and alcohol use, over the lifespan and across generations (de Moor et al., 2011; Geels et al., submitted; Poelen et al., 2005). The original aim was well met: twin designs, and later also extended twin family studies, have shown the degree to which genetic factors impact on a large variety of demographic characteristics (e.g., education, number of offspring), behaviors (e.g., substance use, sport participation), personality traits (e.g., extraversion, disinhibition, neuroticism), physical health aspects (e.g., body mass index (BMI), asthma, blood pressure), mental health (e.g., depression, borderline personality, and ADHD), and cognition (e.g., general IQ, memory).

NTR studies were among the first to show that the heritability for nicotine and alcohol use is relatively low during initiation and increases with the severity of use (Koopmans \& Boomsma, 1996; Vink et al., 2005). NTR data were included in many international collaborations and though the prevalence or means of the trait of interest may differ (e.g., the Dutch participate more in sport more often and are taller than many other populations; Silventoinen et al., 2003; Vink et al., 2011a), heritability estimates were generally comparable to other European populations. This was even the case for the heritability of marihuana use, despite the large differences in international policies (Vink et al., 2010). Gene x environment interactions have also been explored, showing for instance that the heritabil- ity of alcohol initiation and neuroticism depended on religious upbringing (Koopmans et al., 1999; Willemsen \& Boomsma, 2007), while interactions with life events were found for borderline personality (Distel et al., 2011). Despite much study, no interactions of life events and the heritability of depression were found in the ANTR (Middeldorp et al., 2010), contributing to the recent debate on this topic (Duncan \& Keller, 2011). For adulthood ADHD (Boomsma et al., 2010; Saviouk et al., 2011) significant genetic, but no cultural transmission was seen. Genetic factors were found to contribute to somatic diseases such as asthma (Willemsen et al., 2008) and migraine (Ligthart et al., 2011). Beyond the estimation of heritability, twin family data were used to determine the causal mechanisms for comorbid traits, such as depression and sport participation (de Moor et al., 2008) and migraine and depression (Ligthart et al., 2010).

In addition to three extensive cardiovascular studies in the laboratory, the ANTR has created the largest data set to date on 24-hour ambulatory recordings of the impedance cardiogram, and has shown that heritable factors play an important role in individual variation in autonomic nervous system activity (De Geus et al., 2007a; Kupper et al, 2006). Several MRI and EEG projects have established the genetic contributions to brain structure and function (e.g., Smit et al., 2007, 2012).

The genotypic data collection has also proven to be very valuable. Both linkage and whole genome association (GWA) studies have been conducted and the ANTR contributed in several large international gene-finding consortia, such as ENGAGE (European Network for Genetic and Genomic Epidemiology), MAGIC (Meta-Analyses of Glucose and Insulin-related traits Consortium), and PGC (Psychiatric Genetics Consortium), and with success: new genes were detected for traits such as height (Lango Allen et al., 2010), BMI (Speliotes et al., 2010), menarche (Elks et al., 2010), smoking (Thorgeirsson et al., 2010; Tobacco and Genetics Consortium, 2010; Vink et al., 2009), and glucose metabolism (Dupuis et al., 2010).

\section{Future Projects in the ANTR}

The extensive longitudinal phenotypic data collection coupled with in-depth genotypic profiling means that the ANTR will be able to continue its contribution to the study of mental and physical health, exploring both environmental and genetic mechanisms. Preparations have started for the 10th survey that will be sent out early in 2013. This survey will focus on substance use and health, and participants will again be offered the choice of completion by pen-and-paper or online. To reduce the number of incorrect addresses, the ANTR is currently linking up to central address databases.

In addition to the ongoing survey collection, in-depth biological phenotyping also continues. Adult twins and family members currently participate in large-scale projects 
on neuropsychological function and ambulatory monitoring of the autonomic nervous system. The blood and feces samples collected in the second biobank project are used to extract data on the immunogenome and gut microbiome. Furthermore, within existing projects, additional information is becoming available. For instance, metabolomic data have been obtained for 1,889 participants using the massspectrometry-based Biocrates platform. Pilot studies obtaining data by plasma liquid chromatography-mass spectrometry (LC-MS) lipidomics and ${ }^{1} \mathrm{H}$ nuclear magnetic resonance ( ${ }^{1} \mathrm{H}$ NMRB) spectroscopy in NTR biobank samples showed the feasibility of such studies (Draisma et al., 2010, 2012) and plasma samples for almost 4,000 participants are now being measured with ${ }^{1} \mathrm{H}$ NMR. For approximately 3,000 of these participants, we will also have LC-MS lipidomics data. Furthermore, telomere length has been measured in the DNA samples of the two biobanking projects. We also continue to expand genetic information available. Copy number variation is made available for more than 5,000 participants, and as part of the Genome of the Netherlands project, sequencing data were obtained in 347 NTR participants (parents and one or two children). Finally, 13,658 NTR participants (97\% of those asked) have provided permission to link to national databases on morbidity and mortality. The first trials with linking our longitudinal data to the national cancer registration are ongoing, and linking to the Dutch pathology database has already proven successful (Vink et al., 2011b). This will greatly facilitate comprehensive studies of the etiology of health, lifestyle, and personality across the lifespan. In short, the ANTR is ready for the next 25 years.

\section{Acknowledgments}

We would like to thank all the twins and family members who participated in ANTR research over the past 25 years. We also would like to thank the funding agencies for their support in these years: the Netherlands Organisation for Scientific Research, NWO (900-562-137, 904-61090, 985-10-002, 904-61-193, 56-464-14192, 400-03-330, 480-04-004, 400-07-080, 911-09-032, 451-06-004, 451-08026, 451-10-005), NWO-DFG (DN 58-103), the Netherlands Organisation for Health Research and Development (ZonMW 3100.0038, 940-37-024, 31160008), EMGO+ Institute for Health and Care Research, Neuroscience Campus Amsterdam, Center for Medical Systems Biology (CMSB), Netherlands Brain Foundation (13F-05(2).47), BBMRI NL (184.021.007: Biobanking and Biomolecular Resources Research Infrastructure), GENOMEUTWIN/EU (QLG2CT-2002-01254), National Institutes of Health (NIH 5R37DA018673-03, R01 MH059160, 1RC2 MH08995101, 4R37DA018673-06, 1R01 MH087646-01A1), National Institute of Mental Health (RFA MH08120), Brain and Behavior Research Foundation (2011 NARSAD Distinguished Investigator Grant), FP7 ENGAGE (FP7-HEALTH-
F4-2007-201413), EU-Marie Curie Research Training Networks (MRTN ct-2006 035987), European Research Council (230374-GMI, 284167), Rutgers University (3797).

\section{References}

Abdellaoui, A., Hottenga, J. J., de Knijff, P., Nivard, M. G., Xiao, $\mathrm{X}$, Scheet, P., ... Boomsma, D. I. (submitted). Increasing genome-wide ancestry signals to study population structure. Manuscript submitted for publication.

Alders, M. (2002). Allochtonenprognose 2002-2050: Bijna twee miljoen niet-westerse allochtonen in 2010. [Immigrant prognosis 2002-2050: Almost two million non-western immigrants in 2010.] Bevolkingstrends, 1e kwartaal 2003, 34-41. Statistics Netherlands. Accessed on $1^{\text {st }}$ November, 2012. Retrieved from http://www.cbs.nl/NR/ rdonlyres/900AFF25-7E54-4F8C-92DE-435270FD3E68/0/ 2003k1b15p034art.pdf.

Baaré, W. F., Hulshoff Pol, H. E., Boomsma, D. I., Posthuma, D., de Geus, E. J. C., Schnack, H. G., . . Kahn, R. S. (2001). Quantitative genetic modeling of variation in human brain morphology. Cerebral Cortex, 11, 816-824.

Boomsma, D. I., Beem, A. L., Van den Berg, M., Dolan, C. V., Koopmans, J. R., Vink, J. M., ... Slagboom, P. E. (2000). Netherlands twin family study of anxious depression (NETSAD). Twin Research, 3, 323-334.

Boomsma, D. I., de Geus, E. J. C., Vink, J. M., Stubbe, J. H., Distel, M. A., Hottenga, J. J., ... Willemsen, G. (2006). Netherlands Twin Register: From twins to twin families. Twin Research and Human Genetics, 9, 849-857.

Boomsma, D. I., Kempen, H. J., Gevers Leuven, J. A., Havekes, L., de Knijff, P., \& Frants, R. R. (1996). Genetic analysis of sex and generation differences in plasma lipid, lipoprotein, and apolipoprotein levels in adolescent twins and their parents. Genetic Epidemiology, 13, 49-60.

Boomsma, D. I., Saviouk, V., Hottenga, J. J., Distel, M. A., de Moor, M. H., Vink, J. M., ... Willemsen, G. (2010). Genetic epidemiology of attention deficit hyperactivity disorder (ADHD index) in adults. PLoS One, 5, e10621.

Boomsma, D. I., Vink, J. M., van Beijsterveldt, C. E. M., de Geus, E. J. C., Beem, A. L., Mulder, E. J. C. M., . . van Baal, G. C. M. (2002). Netherlands Twin Register: A focus on longitudinal research. Twin Research, 5, 401-406.

Boomsma, D. I., Willemsen, G., Sullivan, P. F., Heutink, P., Meijer, P., Sondervan, D., . . Penninx, B. W. J. H. (2008). Genome-wide association of major depression: Description of samples for the GAIN Major Depressive Disorder Study: NTR and NESDA biobank project. European Journal of Human Genetics, 16, 335-342.

De Geus, E. J., Kupper, N., Boomsma, D. I., \& Snieder, H. (2007a). Bivariate genetic modeling of cardiovascular stress reactivity: Does stress uncover genetic variance? Psychosomatic Medicine, 69, 356-364.

De Geus, E. J. C., van't Ent, D., Wolfensberger, S. P., Heutink, P., Hoogendijk, W. J., Boomsma, D. I., \& Veltman, D. J. (2007b). Intrapair differences in hippocampal volume in monozygotic twins discordant for the risk for anxiety and depression. Biological Psychiatry, 61, 10621071. 
De Moor, M. H., Boomsma, D. I., Stubbe, J. H., Willemsen, G., \& de Geus, E. J. (2008). Testing causality in the association between regular exercise and symptoms of anxiety and depression. Archives of General Psychiatry, 65, 897905.

De Moor, M. H., Willemsen, G., Rebollo-Mesa, I., Stubbe, J. H., De Geus, E. J., \& Boomsma, D. I. (2011). Exercise participation in adolescents and their parents: Evidence for genetic and generation specific environmental effects. Behavior Genetics, 41, 211-222.

den Braber, A., van 't Ent, D., Boomsma, D. I., Cath, D. C., Veltman, D. J., Thompson, P. M., \& de Geus, E. J. C. (2011). White matter differences in monozygotic twins discordant or concordant for obsessive-compulsive symptoms: A combined diffusion tensor imaging/voxel-based morphometry study. Biological Psychiatry, 70, 969-977.

den Braber, A., van 't Ent, D., Cath, D. C., Veltman, D. J., Boomsma, D. I., \& de Geus, E. J. C. (2012). Brain activation during response interference in twins discordant or concordant for obsessive compulsive symptoms. Twin Research and Human Genetics, 15, 372-383.

Distel, M. A., Middeldorp, C. M., Trull, T. J., Derom, C. A., Willemsen, G., \& Boomsma, D. I. (2011). Life events and borderline personality features: The influence of geneenvironment interaction and gene-environment correlation. Psychological Medicine, 41, 849-860.

Draisma, H. H. M., Reijmers, T. H., Meulman, J. J., Boomsma, D. I., van der Greef, J., \& Hankemeier, T. (2012). Hierarchical clustering analysis of blood plasma lipidomics profiles from mono- and dizygotic twin families. European Journal of Human Genetics. Advance online publication. doi:10.1038/ejhg.2012.110.

Draisma, H. H. M., Reijmers, T. H., van der Kloet, F., Bobeldijk-Pastorova, I., Spies-Faber, E., Vogels, J. T., ... Hankemeier, T. (2010). Equating, or correction for between-block effects with application to body fluid LC-MS and NMR metabolomics data sets. Analytical Chemistry, 82, 1039-1046.

Duncan, L. E., \& Keller, M. C. (2011). A critical review of the first 10 years of candidate gene-by-environment Interaction research in psychiatry. American Journal of Psychiatry, 168, 1041-1049.

Dupuis, J., Langenberg, C., Prokopenko, I., Saxena, R., Soranzo, N., Jackson, A. U., ... Barroso, I. (2010). New genetic loci implicated in fasting glucose homeostasis and their impact on type 2 diabetes risk. Nature Genetics, 42, 105-116.

Ehli, E. A., Abdellaoui, A., Hu, Y., Hottenga, J. J., Kattenberg, M., van Beijsterveldt, T., ... Davies, G. E. (2012). De novo and inherited CNVs in $\mathrm{MZ}$ twin pairs selected for discordance and concordance on attention problems. European Journal of Human Genetics, 20(10), 1037-1043.

Elks, C. E., Perry, J. R., Sulem, P., Chasman, D. I., Franceschini, N., He, C., .. Murray, A. (2010). Thirty new loci for age at menarche identified by a meta-analysis of genome-wide association studies. Nature Genetics, 42, 1077-1085.

Geels, L. M., Vink, J. M., van Beek, J. H. D. A., Bartels, M., Willemsen, G., \& Boomsma, D. I. (submitted). Increases in alcohol consumption in Dutch women and elderly groups: Evidence from an epidemiological study. Manuscript submitted for publication.

Hoekstra, C., Willemsen, G., van Beijsterveldt, T. C., Montgomery, G. W., \& Boomsma, D. I. (2008). Familial twinning and fertility in Dutch mothers of twins. American Journal of Medical Genetics, 146A, 3147-3156.

Hottenga, J. J., Whitfield, J. B., Posthuma, D., Willemsen, G., de Geus, E. J., Martin, N. G., \& Boomsma, D. I. (2007). Genome-wide scan for blood pressure in Australian and Dutch subjects suggests linkage at 5P, 14Q, and 17P. Hypertension, 49, 832-838.

Jansen, R., Batista, S., Willemsen, G., van Grootheest, G., Madar, V., Peyrot, W., ... Penninx, B. W. J. H. (submitted). Sex differences in the human peripheral blood transcriptome. Manuscript submitted for publication.

Koopmans, J. R., \& Boomsma, D. I. (1996). Familial resemblances in alcohol use: Genetic or cultural transmission? Journal of Studies on Alcohol, 57, 19-28.

Koopmans, J. R., Slutske, W. S., van Baal, G. C. M., \& Boomsma, D. I. (1999). The influence of religion on alcohol use initiation: Evidence for genotype X environment interaction. Behavior Genetics, 29, 445-453.

Kupper, N., de Geus, E. J., van den Berg, M., Kirschbaum, C., Boomsma, D. I., \& Willemsen, G. (2005). Familial influences on basal salivary cortisol in an adult population. Psychoneuroendocrinology, 30, 857-868.

Kupper, N., Willemsen, G., Boomsma, D. I., \& de Geus, E. J. (2006). Heritability of indices for cardiac contractility in ambulatory recordings. Journal of Cardiovascular Electrophysiology, 17, 877-883.

Lango Allen, H., Estrada, K., Lettre, G., Berndt, S. I., Weedon, M. N., Rivadeneira, F., ... Hirschhorn, J. N. (2010). Hundreds of variants clustered in genomic loci and biological pathways affect human height. Nature, 467, 832838.

Ligthart, L., de Vries, B., Smith, A.V., Ikram, M. A., Amin, N., Hottenga, J. J., . . Boomsma, D. I. (2011). Meta-analysis of genome-wide association for migraine in six populationbased European cohorts. European Journal of Human Genetics, 19, 901-907.

Ligthart, L., Nyholt, D. R., Penninx, B. W., \& Boomsma, D. I. (2010). The shared genetics of migraine and anxious depression. Headache, 50, 1549-1560.

Middeldorp, C. M., de Geus, E. J. C., Willemsen, G., Hottenga, J. J., Slagboom, P. E., \& Boomsma, D. I. (2010). The serotonin transporter gene length polymorphism (5-HTTLPR) and life events: No evidence for an interaction effect on neuroticism and anxious depressive symptoms. Twin Research and Human Genetics, 13, 544-549.

Painter, J. N., Willemsen, G., Nyholt, D., Hoekstra, C., Duffy, D. L., Henders, A. K., ... Montgomery, G. W. (2010). A genome wide linkage scan for dizygotic twinning in 525 families of mothers of dizygotic twins. Human Reproduction, 25, 1569-1580.

Poelen, E. A., Scholte, R. H., Engels, R. C., Boomsma, D. I., \& Willemsen, G. (2005). Prevalence and trends of alcohol use and misuse among adolescents and young adults in the 
Netherlands from 1993 to 2000. Drug and Alcohol Dependency, 79, 413-421.

Posthuma, D., Luciano, M., Geus, E. J., Wright, M. J., Slagboom, P. E., Montgomery, G. W.,... Martin, N. G. (2005). A genomewide scan for intelligence identifies quantitative trait loci on $2 \mathrm{q}$ and $6 \mathrm{p}$. American Journal of Human Genetics, 77, 318-326.

Posthuma, D., Mulder, E. J., Boomsma, D. I., \& de Geus, E. J. (2002). Genetic analysis of IQ, processing speed and stimulus-response incongruency effects. Biological Psychology, 61, 157-182.

Reiling, E., Ling, C., Uitterlinden, A. G., Van't Riet, E., Welschen, L. M., Ladenvall, C., ... 't Hart, L. M. (2010). The association of mitochondrial content with prevalent and incident type 2 diabetes. Journal of Clinical Endocrinology \& Metabolism, 95, 1909-1915.

Saviouk, V., Hottenga, J. J., Slagboom, E. P., Distel, M. A., de Geus, E. J., Willemsen, G., \& Boomsma, D. I. (2011). ADHD in Dutch adults: Heritability and linkage study. American Journal of Medical Genetics Part B: Neuropsychiaticr Genetics, 156B, 352-362.

Scheet, P., Ehli, E. A., Xiao, X., van Beijsterveldt, C. E. M., Abdellaoui, A., Althoff, R. R., ... Boomsma, D. I. (2012). Twins, tissue and time: An Assessment of SNPs and CNVs. Twin Research and Human Genetics, 28, 1-9.

Silventoinen, K., Sammalisto, S., Perola, M., Boomsma, D. I., Cornes, B. K., Davis, C., .. Kaprio, J. (2003). Heritability of adult body height: A comparative study of twin cohorts in eight countries. Twin Research, 6, 399-408.

Simonis-Bik, A. M., Eekhoff, E. M., Diamant, M., Boomsma, D. I., Heine, R. J., Dekker, J. M., . . . de Geus, E. J. (2008). The heritability of HbA1c and fasting blood glucose in different measurement settings. Twin Research and Human Genetics, 11, 597-602.

Smit, D. J., Boomsma, D. I., Schnack, H. G., Hulshoff Pol, H. E., \& de Geus, E. J. C (2012). Individual differences in EEG spectral power reflect genetic variance in gray and white matter volumes. Twin Research and Human Genetics, 15, 384-392.

Smit, D. J., Posthuma, D., Boomsma, D. I., \& de Geus, E. J. C. (2007). Genetic contribution to the P3 in young and middle-aged adults. Twin Research and Human Genetics, 10, 335-347.

Snieder, H., van Doornen, L. J., \& Boomsma, D. I. (1997). The age dependency of gene expression for plasma lipids, lipoproteins, and apolipoproteins. American Journal of $\mathrm{Hu}$ man Genetics, 60, 638-650.

Speliotes, E. K., Willer, C. J., Berndt, S. I., Monda, K. L., Thorleifsson, G., Jackson, A. U., ... Loos, R. J. (2010). Association analyses of 249,796 individuals reveal 18 new loci associated with body mass index. Nature Genetics, 42, 937948.

Sullivan, P. F., de Geus, E. J. C., Willemsen, G., James, M. R., Smit, J. H., Zandbelt, T., . . Penninx, B. W. (2009). Genomewide association for major depressive disorder: A possible role for the presynaptic protein piccolo. Molecular Psychiatry, 14, 359-375.
Talens, R. P., Christensen, K., Putter, H., Willemsen, G., Christiansen, L., Kremer, D., . . Heijmans, B. T. (2012). Epigenetic variation during the adult lifespan: Cross-sectional and longitudinal data on monozygotic twin pairs. Aging Cell, 11, 694-703.

Thorgeirsson, T. E., Gudbjartsson, D. F., Surakka, I., Vink, J. M., Amin, N., Geller, F., Sulem, P., .. . Stefansson, K. (2010). Sequence variants at CHRNB3-CHRNA6 and CYP2A6 affect smoking behavior. Nature Genetics, 42, 448-453.

Tobacco and Genetics Consortium. (2010). Genome-wide meta-analyses identify multiple loci associated with smoking behavior. Nature Genetics, 42, 441-447.

Van Beijsterveldt, C. E. M., Groen-Blokhuis, M., Franic, S., Lamb, D., Huppertz, C., de Zeeuw, E., ... Boomsma, D. I. (2013). The Young Netherlands Twin Registry (YNTR): Longitudinal twin and family studies in over 70,000 children. Twin Research and Human Genetics.

Van Beijsterveldt, C. E., van Baal, G .C., Molenaar, P. C., Boomsma, D. I., \& de Geus, E. J. (2001). Stability of genetic and environmental influences on P300 amplitude: A longitudinal study in adolescent twins. Behavior Genetics, 31, 533-543.

Vink, J. M., Boomsma, D. I., Medland, S. E., de Moor, M. H., Stubbe, J. H., Cornes, B. K., ... de Geus, E. J. C. (2011a). Variance components models for physical activity with age as modifier: A comparative twin study in seven countries. Twin Research and Human Genetics, 14, 25-34.

Vink, J. M., Smit, A. B., de Geus, E. J., Sullivan, P., Willemsen, G., Hottenga, J.J., ... Boomsma, D. I. (2009). Genomewide association study of smoking initiation and current smoking. American Journal of Human Genetics, 84, 367379.

Vink, J. M., van Kemenade, F. J., Meijer, C. J., Casparie, M. K., Meijer, G. A., \& Boomsma, D. I. (2011b). Cervix smear abnormalities: Linking pathology data in female twins, their mothers and sisters. European Journal of Human Genetics, 19, 108-111.

Vink, J. M., Willemsen, G., \& Boomsma, D. I. (2005). Heritability of smoking initiation and nicotine dependence. Behavior Genetics, 35, 397-406.

Vink, J. M., Wolters, L. M., Neale, M. C., \& Boomsma, D. I. (2010). Heritability of cannabis initiation in Dutch adult twins. Addictive Behaviors, 35, 172-174.

Willemsen, G., \& Boomsma, D. I. (2007). Religious upbringing and neuroticism in Dutch twin families. Twin Research and Human Genetics, 10, 327-333.

Willemsen, G., de Geus, E. J. C., Bartels, M., van Beijsterveldt, C. E. M., Brooks, A. I., Estourgie-van Burk, D. A., .. Boomsma, D. I. (2010). The Netherlands Twin Register biobank: A resource for genetic epidemiological studies. Twin Research and Human Genetics, 13, 231245.

Willemsen, G., van Beijsterveldt, T. C., van Baal, C. G., Postma, D., \& Boomsma, D. I. (2008). Heritability of self-reported asthma and allergy: A study in adult Dutch twins, siblings and parents. Twin Research and Human Genetics, 11, 132142. 
Wolfensberger, S. P., Veltman, D. J., Hoogendijk, W. J., Boomsma, D. I., \& de Geus, E. J. C. (2008). Amygdala responses to emotional faces in twins discordant or concordant for the risk for anxiety and depression. Neuroimage, 41, 544-552.
Wu, T., Boezen, H. M., Postma, D. S., Los, H., Postmus, P. E., Snieder, H., \& Boomsma, D. I. (2010). Genetic and environmental influences on objective intermediate asthma phenotypes in Dutch twins. European Respiratory Journal, 36, 261-268. 